\title{
Efektivitas Penggunaan Infografis Pada Perancangan Buku Profil Universitas (Studi Objek Universitas Pembangunan Nasional "Veteran" Jawa Timur)
}

\author{
Widyasari, Aris Sutejo dan Adibah Nurul Yunisya \\ Program Studi Desain Komunikasi Visual, Fakultas Arsitektur dan Desain \\ Universitas Pembangunan Nasional "Veteran" Jawa Timur \\ e-mail: widyasari.dkv@upnjatim.ac.id
}

\begin{abstract}
Abstrak - Adanya perubahan dan perkembangan positif pada kampus UPN "Veteran" Jatim sudah selayaknya dikemas dalam sebuah media yang dapat menyajikan informasi profil UPN "Veteran" Jatim dengan cara yang menarik dan mudah dipahami. Media tersebut berupa buku profil UPN "Veteran" Jatim yang dirancang dengan menggunakan teknik infografis yakni jenis gambar yang memadukan informasi dengan desain, yang bertujuan untuk berkomunikasi secara singkat dan jelas kepada pembaca.

Metode penelitian yang digunakan adalah metode kualitatif dan kuantitatif dengan langkah-langkah mencari literatur, mengumpulkan data kualitatif dan kuantitatif, menganalisis data dengan menggunakan tabel TOWS (Threat, Opportunities, Weakness, Strength) matrix untuk menentukan Unique Selling Proposition, menganalisis insight target audiens untuk menyusun solusi kreatif, menganalisis dan menyimpulkan hasil kuesioner untuk mengukur capaian penelitian. Dari hasil analisis TOWS matrix dapat disimpulkan bahwa Unique Selling Proposition yang ditemukan adalah UPN "Veteran" Jatim sebagai Perguruan Tinggi Negeri baru terakreditasi " $A$ " yang konsisten dalam menerapkan karakter Bela Negara pada kegiatan akademik dan non-akademik. Unique Selling Proposition inilah yang menjadi konten pada buku profil UPN "Veteran" Jatim. Sedangkan dari hasil analisis consumer insight dapat disimpulkan bahwa audiens menginginkan penyampaian informasi profil UPN "Veteran" Jatim berupa informasi tekstual yang disertai dengan elemen-elemen visual seperti unsur grafis, ilustrasi, pictogram, dan grafik.

Hasil dari penelitian adalah sebesar $83 \%$ (sangat kuat) setuju jika penggunaan infografis berupa unsur grafis, ilustrasi, pictogram, dan grafik pada perancangan buku profil UPN "Veteran" Jatim dapat memiliki tampilan visual yang lebih menarik. Selanjutnya sebesar $83,2 \%$ (sangat kuat) setuju jika penggunaan infografis berupa unsur grafis, ilustrasi, pictogram, dan grafik pada perancangan buku profil UPN "Veteran " Jatim dapat menyajikan informasi menjadi lebih mudah dipahami.
\end{abstract}

Kata kunci: grafik, ilustrasi, infografis, pictogram, dan unsur grafis

Abstract - The emergence of transformation and positive development within Universitas Pembangunan Nasional “Veteran" Jawa Timur (UPN “Veteran” Jatim) supposedly bundled as a media which could provide the information of UPN "Veteran" East Java profile with interesting way and to be easily understood. The media is profile book of UPN "Veteran" Jatim that are designed using the infographic method which is a type of image that combines information with design that aims to communicate briefly and clearly to the reader.
The research method that are used are qualitative and quantitative methods with the research steps consist of searching literature, collecting qualitative data and quantitative data, data analysis using TOWS (Threat, Opportunities, Weakness, Strength) table matrix to define the Unique Selling Proposition, analyzing the targeted audience's insight to compose the creative solution, analyzing and concluding the results of the questionnaire to measure research achievements. From the results of the TOWS matrix analysis, it can be concluded that the Unique Selling Proposition is UPN "Veteran" Jatim as a newly Public Universities with accredited "A", is the consistency in applying the character of Bela Negara to academic and nonacademic activities. This Unique Selling Proposition is the content in the book profile of UPN "Veteran" Jatim. While from the results of the consumer insight analysis, it was concluded that the audience wanted the delivery of information on the profile of UPN "Veteran" Jatim is textual information accompanied by visual elements such as elements of graphics, illustrations, pictograms, and graphics.

The results of this study are as much as 83\% (very strong) agree if the use of infographics in the form of elements of graphics, illustrations, pictograms and graphs, in designing the book profile of UPN "Veteran" Jatim, can illustrate a more interesting visual appearance. Furthermore, 83,2\% (very strong) agreed that the use of infographics in the form of graphic elements, illustrations, pictograms, and graphs in designing the book profile of UPN "Veteran" East Java could present information to be more easily understood.

Keywords: graphs, graphic elements, illustration, infographic, and pictogram

\section{PENDAHULUAN}

Sejak beralih status menjadi Perguruan Tinggi Negeri (PTN), Kampus Universitas Pembangunan Nasional "Veteran" Jawa Timur (UPN "Veteran" Jatim) mengalami beberapa perubahan dan perkembangan yang positif, seperti tata kelola kampus, pembangunan infrastruktur kampus, ketersediaan sarana dan prasarana kampus, prestasi akademis dan non akademis, hingga konsistensi penerapan karakter Bela Negara pada beberapa kegiatan di lingkungan kampus. Adanya perubahan dan perkembangan yang positif ini sudah selayaknya dapat dikemas dalam bentuk profil UPN "Veteran" Jatim sebagai langkah awal untuk membangun image positif kampus agar mudah dikenal dan diingat oleh masyarakat.

Selama ini UPN "Veteran" Jatim menggunakan media website untuk memaparkan profil UPN "Veteran" Jatim dengan memuat informasi yang begitu banyak dan cenderung disajikan dalam bentuk teks sehingga menimbulkan rasa bosan saat membaca. Teks 
yang begitu banyak dan tidak didukung dengan visualisasi yang menarik dapat menyebabkan ketidaktertarikan pembaca dalam membaca konten informasi secara keseluruhan. Selain itu, teks yang begitu banyak juga dapat menyebabkan pembaca kesulitan dalam memahami maksud dari infomasi tersebut. Sehingga dalam konteks ini dibutuhkan perancangan sebuah media yang dapat menyajikan informasi profil UPN "Veteran" Jatim dengan cara yang menarik dan mudah dipahami, yakni buku profil UPN "Veteran" Jatim yang dirancang dengan menggunakan teknik infografis.

Infografis (inpographic) merupakan singkatan dari 'grafis informasi', adalah jenis gambar yang memadukan informasi dengan desain, yang bertujuan membantu individu dan organisasi untuk berkomunikasi secara singkat dan jelas kepada pembaca. Infografis dapat menyajikan materi kepada pembaca secara lebih ringkas namun tetap jelas karena disertai dengan gambar-gambar dan informasi yang mendukung. Infografis mengilustrasikan informasi yang memiliki sedikit teks dan berperan sebagai ringkasan visual. Dalam infografis terdapat beberapa elemen seperti data, informasi, pengetahuan, serta gambar dengan sedikit teks yang semuanya dituangkan ke dalam bentuk desain grafis.

\section{TINJAUAN PUSTAKA}

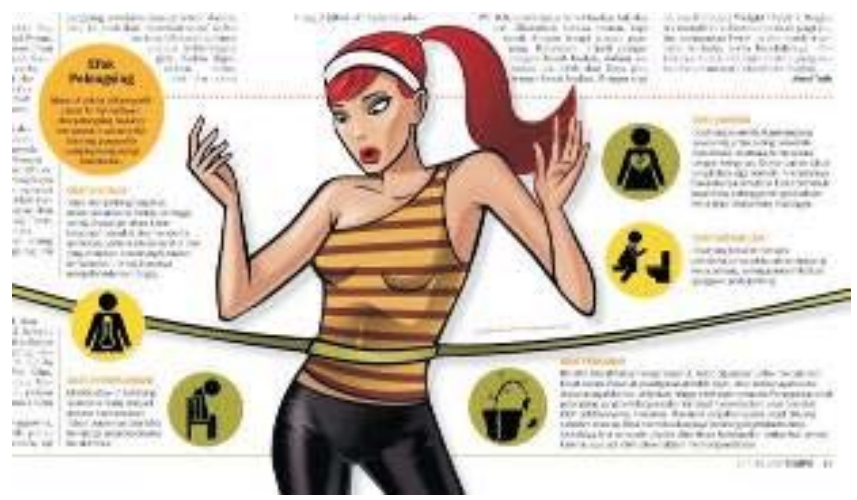

Gambar 1. Penyampaian informasi menggunakan teknik infografis yang diserta dengan pictogram

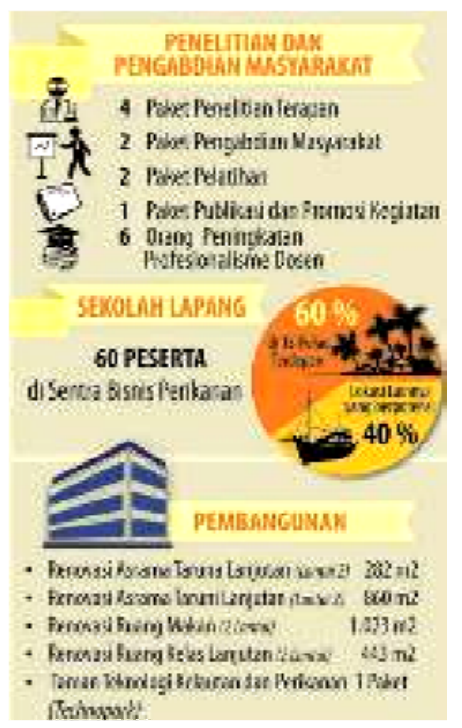

Gambar 2. Penyampaian informasi menggunakan teknik infografis yang disertai dengan ilustrasi dan diagram.

\section{A. Definisi Infografis}

Infografis yaitu kependekan dari 'grafis informasi', menggunakan isyarat-isyarat visual untuk mengkomunikasikan sebuah informasi. Istilah infografis mengacu pada penggunaan perangkat visual dengan maksud untuk mengkomunikasikan informasi yang kompleks secara cepat dan jelas. Infografis dapat dibuat dengan berbagai macam teknik, tergantung dari pesan yang akan disampaikan (Gambar 1 dan Gambar 2). Infografis yang baik merupakan kehandalan desainer dalam menyampaikan sebuah informasi yang tidak hanya mudah dipahami namun juga lebih menarik dan lebih dinikmati daripada hanya sekedar membaca teksnya saja [1], [2], [3] dan [4].

\section{B. Sains Tentang Kelebihan Infografis}

Berikut adalah beberapa hasil penelitian yang berkaitan dengan kelebihan infografis yang telah dirangkum [5], [6], dan [7].

1. Penglihatan menempati bagian yang sangat besar di otak.

2. Penyampaian informasi menggunakan infografis lebih mudah diproses oleh otak daripada hanya menggunakan teks saja.

3. Otak dirancang untuk mencari sesuatu yang berbeda.

4. Mayoritas masyarakat adalah pembelajar visual.

\section{METODE PENELITIAN}

Metode penelitian yang digunakan pada penelitian ini adalah metode kualitatif dan kuantitatif. Metode kualitatif digunakan untuk merancang buku profil UPN "Veteran" Jatim yang disajikan dengan menggunakan teknik infografis. Sedangkan metode kuantitatif digunakan untuk mengukur efektivitas penggunaan teknik infografis pada perancangan buku profil UPN "Veteran" Jatim.

Penelitian kualitatif bersifat fleksibel dan dapat berubah-ubah sesuai dengan kondisi lapangan. Data kualitatif merupakan data yang diperoleh bukan dalam bentuk angka, tetapi dalam bentuk teks, dokumen, gambar, foto, artefak, atau objek-objek lainnya yang ditemukan di lapangan selama penelitian dilakukan. Sedangkan penelitian kuantitatif merupakan penelitian yang menggunakan proses data-data berupa angka sebagai alat untuk menganalisis dan mengkaji penelitian, terutama mengenai apa saja yang telah diteliti.

Langkah-langkah yang digunakan untuk menyusun penelitian, adalah sebagai berikut:

1. Mencari literatur atau studi pustaka.

2. Mengumpulkan data kualitatif dan data kuantitatif.

3. Menganalisis data dengan menggunakan tabel TOWS (Threat, Opportunities, Weakness, Strength) matrix untuk menentukan Unique Selling Proposition.

4. Menganalisis insight target audiens dengan menggunakan metode why test untuk menyusun solusi kreatif.

5. Menyusun kuesioner untuk mengukur capaian atau tujuan penelitian.

6. Menganalisis dan menyimpulkan hasil kuesioner.

\section{A. Teknik Pengumpulan Data}

Teknik pengumpulan data yang digunakan pada penelitian ini adalah teknik pengumpulan data kualitatif dan teknik pengumpulan data kuantitatif. Teknik pengumpulan data kualitatif meliputi kepustakaan, dokumentasi, observasi, dan wawancara, sedangkan teknik pengumpulan data kuantitatif berupa kuesioner.

1. Kepustakaan

Kepustakaan digunakan untuk mencari data literatur yang berhubungan dengan infografis, pictogram, dan unsur-unsur desain komunikasi visual yang erat kaitannya dengan objek penelitian.

2. Dokumentasi

Dokumentasi dilakukan untuk mendokumentasikan data-data yang berhubungan dengan informasi profil UPN "Veteran" Jatim.

3. Observasi

Observasi dilakukan secara langsung untuk mendapatkan data-data kondisi fisik objek penelitian di lingkungan UPN "Veteran" Jatim. 4. Wawancara

Wawancara dilakukan secara langsung kepada pihak-pihak yang berkaitan dengan pencarian data penelitian. Wawancara yang pertama dilakukan kepada pihak-pihak yang menjadi narasumber 
dalam penggalian data tentang profil UPN "Veteran" Jatim. Sedangkan wawancara yang kedua dilakukan kepada target audiens yang menjadi sasaran dalam perancangan buku profil UPN "Veteran" Jatim.

\section{Kuesioner}

Kuesioner dilakukan untuk mengukur capaian atau tujuan penelitian. Kuesioner mencangkup pertanyaan-pertanyaan mengenai efektivitas penggunaan teknik infografis pada perancangan buku profil UPN "Veteran" Jatim. Penyebaran kuesioner dilakukan kepada responden yang menjadi sampel dalam penelitian.

\section{B. Teknik Analisis Data}

Analisis data merupakan suatu proses menata, menyetrukturkan, dan memaknai data yang tidak beraturan. Analisis data yang digunakan pada penelitian ini adalah analisis data kualitatif dan analisis data kuantitatif. Analisis data kualitatif merupakan proses sistematis yang terus-menerus berlangsung bersamaan dengan pengumpulan data. Sedangkan analisis data kuantitatif merupakan angka-angka (kuantitas) yang diperoleh dari jumlah suatu penggabungan atau pengukuran [8], [9] dan [10].

1. Analisis TOWS Matrix

Data hasil observasi di lingkungan UPN "Veteran" Jatim dan hasil wawancara kepada narasumber dilakukan analisis dengan menggunakan tabel TOWS (Threat, Opportunities, Weakness, Strength) matrix. Analisis yang pertama digunakan untuk menentukan unique selling proposition, dengan cara mencari kesamaan yang paling menonjol antara kekuatan (strength) dan peluang (opportunities). Sedangkan analisis yang kedua digunakan untuk menentukan strategi kreatif.

2. Analisis Consumer Insight

Data hasil wawancara kepada target audiens dilakukan analisis consumer insight dengan menggunakan metode why test. Hasil wawancara tersebut memiliki insight yang bermacam-macam. Penggunaan insight yang unik merupakan solusi kreatif untuk menawarkan gagasan yang lebih segar [11] dan [12].

3. Analisis Kuesioner

Data hasil penyebaran kuesioner kepada responden dilakukan perhitungan skor untuk setiap jawaban dari indikator pertanyaan kuesioner dan membuat kesimpulan persentase dari hasil kuesioner tersebut.

\section{HASIL DAN PEMBAHASAN}

Efektivitas penggunaan infografis pada perancangan buku profil Universitas dengan studi objek UPN "Veteran" Jatim merupakan perancangan buku profil UPN "Veteran" Jatim yang disajikan dengan menggunakan teknik infografis yang kemudian diukur bagaimana efektivitasnya. Infografis yakni jenis gambar yang memadukan informasi dengan desain, dengan tujuan untuk membantu individu dan organisasi untuk berkomunikasi secara singkat dan jelas kepada pembaca. Gambar 3 merupakan skema keunggulan penggunaan teknik infografis dalam perancangan buku profil UPN "Veteran" Jatim:

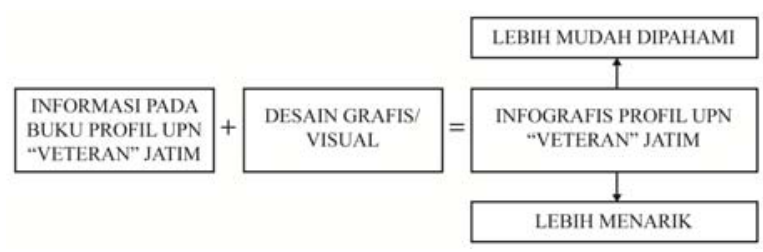

Gambar 3. Skema keunggulan penggunaan teknik infografis pada perancangan buku profil UPN "Veteran" Jatim.

A. Informasi Buku Profil UPN "Veteran" Jatim

Dari hasil analisis TOWS matrix dapat disimpulkan bahwa Unique Selling Proposition dari kekuatan (strength) dan peluang (opportunities) yang paling menonjol adalah konsistensi UPN "Veteran" Jatim sebagai Perguruan Tinggi Negeri (PTN) baru terakreditasi "A" dalam menerapkan karakter Bela Negara pada kegiatan akademik dan non-akademik, sehingga image Bela Negara UPN "Veteran" Jatim semakin melekat pada masyarakat dan kepercayaan masyarakat akan meningkat. Unique Selling Proposition inilah yang menjadi konten atau informasi pada buku profil UPN "Veteran" Jatim.

\section{B. Visualisasi Buku Profil UPN "Veteran" Jatim}

Dari hasil analisis consumer insight dengan metode why test disimpulkan bahwa audiens menginginkan penyampaian informasi profil UPN "Veteran" Jatim yang ringkas dan jelas, serta memiliki tampilan visual yang menarik sehingga tidak membosankan ketika dibaca. Solusi kreatif yang dapat disusun dari consumer insight ini adalah cara penyampaian informasi profil UPN "Veteran" Jatim yang mudah dipahami dan menarik secara visual, yakni penyampaian informasi tekstual yang disertai dengan elemenelemen visual seperti unsur grafis, ilustrasi, pictogram, dan grafik. Cara penyampaian informasi seperti ini digunakan agar informasi menjadi lebih mudah dipahami, memiliki tampilan yang lebih menarik, serta dapat memperkuat image kampus Bela Negara UPN "Veteran" Jatim (lihat Gambar 4).

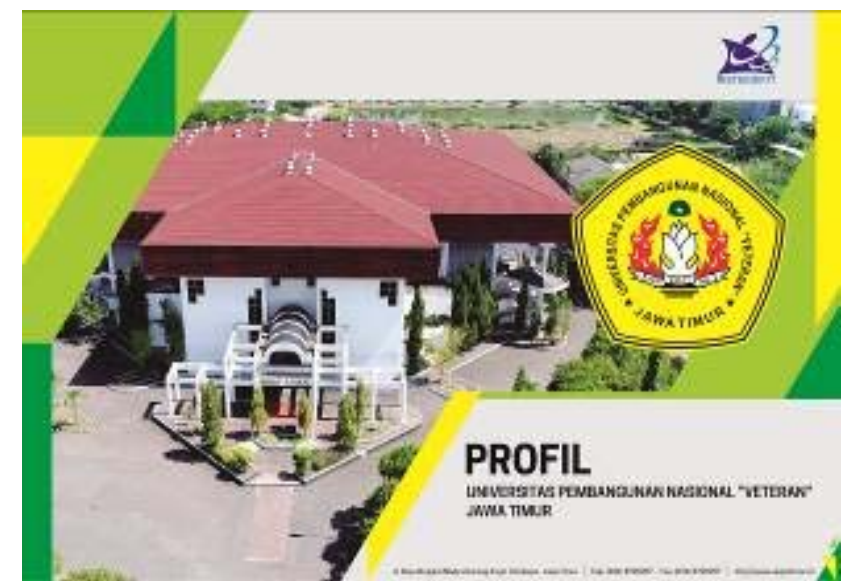

Gambar 4. Penerapan unsur grafis bentuk dan warna menjadi supergrafis pada layout buku profil UPN "Veteran" Jatim.

1. Unsur Grafis

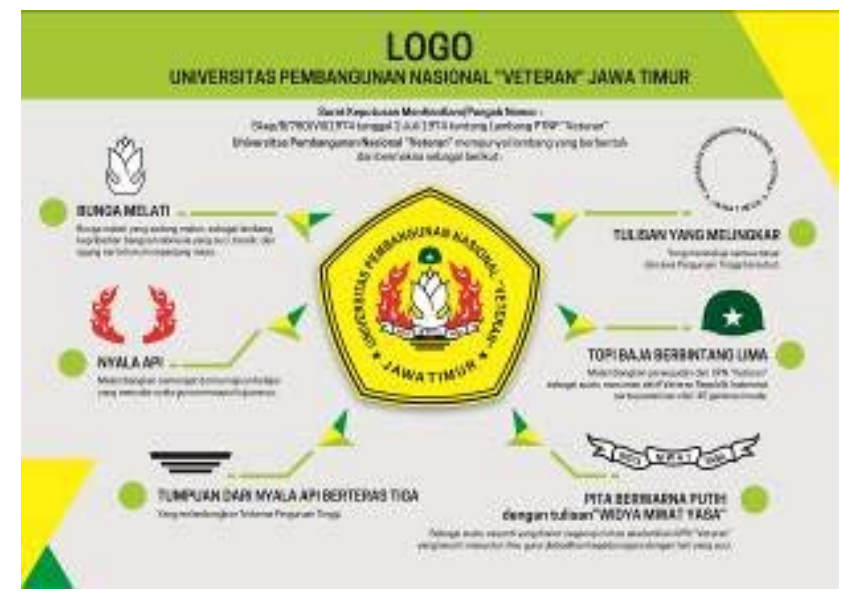

Gambar 5. Penggunaan teknik infografis dengan unsur grafis bentuk dan warna dalam penyampaian informasi filosofi logo UPN "Veteran" Jatim.

Unsur grafis (Gambar 5) yang digunakan pada visualisasi buku profil UPN "Veteran" Jatim adalah unsur bentuk dan unsur warna. Unsur bentuk diambil dari penyederhanaan bentuk eksterior bangunan UPN "Veteran" Jatim dengan bentuk dasar geometri dan 
terkesan kaku. Sedangkan unsur warna diambil dari warna logo UPN "Veteran" Jatim dan warna militer untuk menyimbolkan karakter Bela Negara UPN "Veteran" Jatim yakni warna kuning dan warna hijau. Selanjutnya unsur bentuk dan unsur warna tersebut diterapkan sebagai supergrafis pada layout buku profil UPN "Veteran" Jatim. Supergrafis merupakan turunan dari logo/ identitas visual yang dapat berfungsi sebagai sistem grafis media dan juga dapat memperkuat image sebuah instansi.

Efektivitas dari penggunaan infografis berupa unsur grafis bentuk dan warna pada perancangan buku profil UPN "Veteran" Jatim dapat diukur melalui hasil kuesioner yang telah disebarkan kepada 50 responden. Dari hasil kuesioner dapat disimpulkan bahwa sebesar $82,2 \%$ (sangat kuat) setuju jika penggunaan infografis berupa unsur grafis bentuk dan warna pada perancangan buku profil UPN "Veteran" Jatim dapat memiliki tampilan visual yang lebih menarik. Kemudian juga dapat disimpulkan sebesar $84,4 \%$ (sangat kuat) setuju jika penggunaan infografis berupa unsur grafis bentuk dan warna pada perancangan buku profil UPN "Veteran" Jatim dapat menyajikan informasi menjadi lebih mudah dipahami.

\section{Ilustrasi}

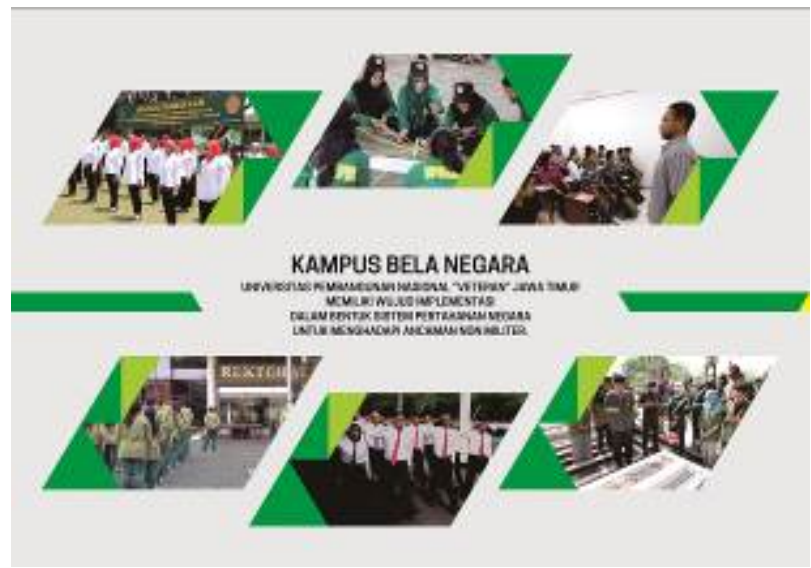

Gambar 6. Penggunaan teknik infografis berupa ilustrasi foto dalam penyampaian informasi kampus Bela Negara UPN "Veteran" Jatim.

Ilustrasi merupakan hasil visualisasi dari sebuah tulisan dengan menggunakan teknik drawing, lukisan, fotografi, atau teknik seni rupa lainnya. Efektivitas dari penggunaan infografis berupa ilustrasi pada perancangan buku profil UPN "Veteran" Jatim dapat diukur melalui hasil kuesioner yang telah disebarkan kepada 50 responden. Dari hasil kuesioner dapat disimpulkan bahwa sebesar $84,4 \%$ (sangat kuat) setuju jika penggunaan infografis berupa ilustrasi pada perancangan buku profil UPN "Veteran" Jatim dapat memiliki tampilan visual yang lebih menarik. Kemudian juga dapat disimpulkan sebesar $84,4 \%$ (sangat kuat) setuju jika penggunaan infografis berupa ilustrasi pada perancangan buku profil UPN "Veteran" Jatim dapat menyajikan informasi menjadi lebih mudah dipahami (lihat gambar 6).

\section{Pictogram}

Pictogram merupakan gambar yang mewakili gagasan dan disampaikan melalui perupaan bentuk fisik obyek aslinya. Informasi yang panjang akan lebih mudah dipahami dengan menggunakan pictogram, karena pictogram berupaya menyederhanakan dan tidak hanya sekedar menyimbolkan. Efektivitas dari penggunaan infografis berupa pictogram pada perancangan buku profil UPN "Veteran" Jatim dapat diukur melalui hasil kuesioner yang telah disebarkan kepada 50 responden. Dari hasil kuesioner dapat disimpulkan bahwa sebesar $77,4 \%$ (kuat) setuju jika penggunaan infografis berupa pictogram pada perancangan buku profil UPN "Veteran" Jatim dapat memiliki tampilan visual yang lebih menarik. Kemudian juga dapat disimpulkan sebesar $82,2 \%$ (sangat kuat) setuju jika penggunaan infografis berupa pictogram pada perancangan buku profil UPN "Veteran" Jatim dapat menyajikan informasi menjadi lebih mudah dipahami seperti pada Gambar 7 dan Gambar 8.

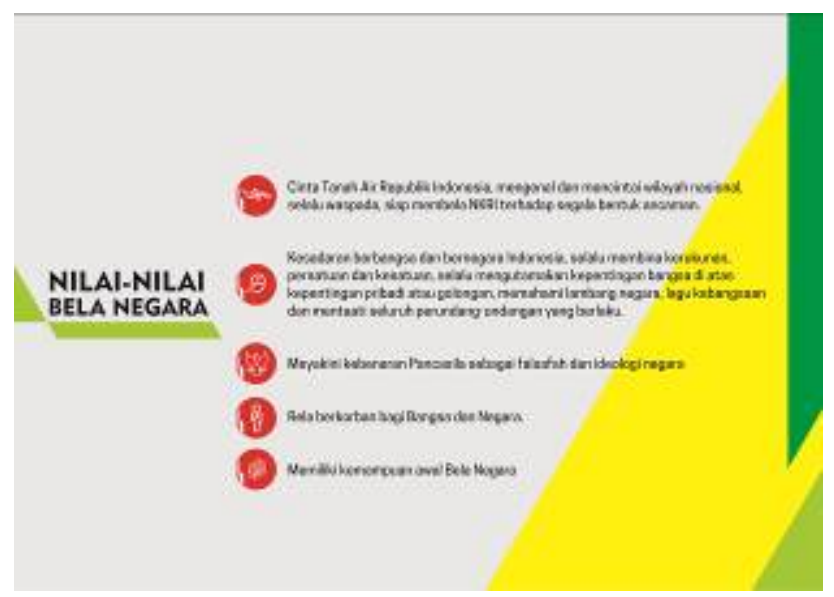

Gambar 7. Penggunaan teknik infografis berupa pictogram dalam penyampaian informasi nilai-nilai Bela Negara UPN "Veteran" Jatim

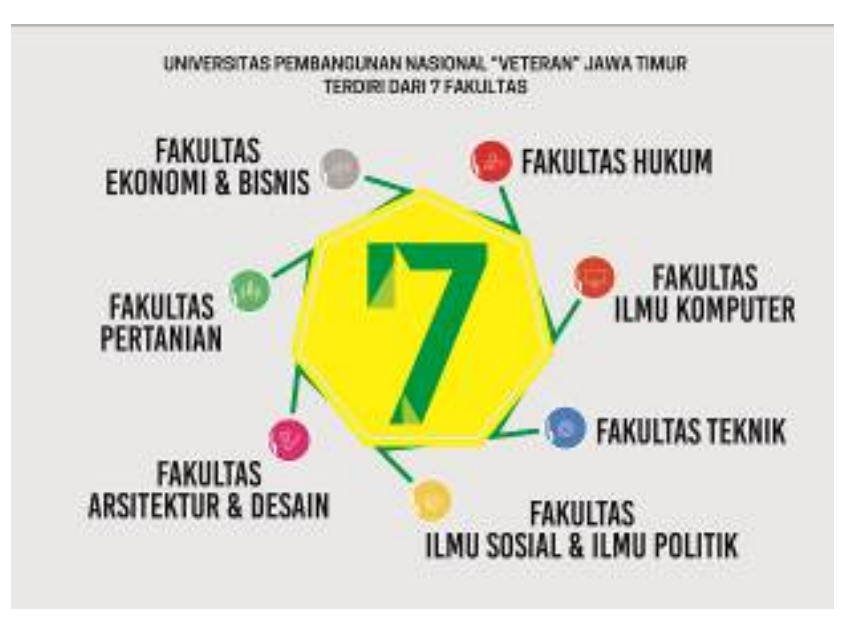

Gambar 8. Penggunaan teknik infografis berupa pictogram dalam penyampaian informasi tujuh Fakultas UPN "Veteran" Jatim

4. Grafik

PERSONEL UNVERSTIAS PEMBANGUNAN NASIONAL "VETERAN" JAWA TIMUR

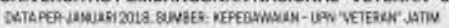

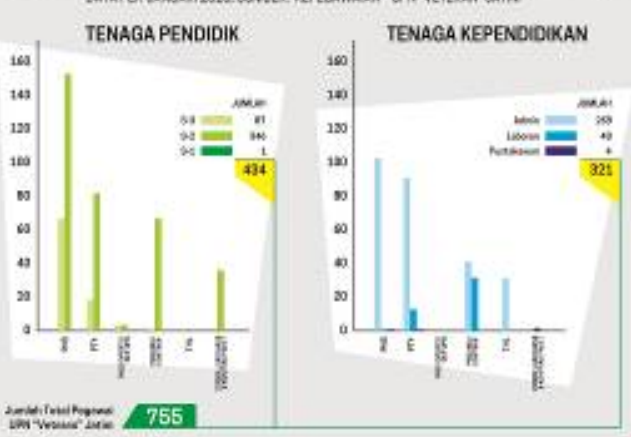

Gambar 9. Penggunaan teknik infografis berupa grafik dalam penyampaian informasi jumlah personel UPN "Veteran" Jatim

Grafik merupakan suatu visualisasi tabel, di mana tabel tersebut berupa angka-angka yang dapat disajikan ataupun dapat ditampilkan dalam bentuk gambar. Jenis grafik yang digunakan dalam menyajikan informasi profil UPN "Veteran" Jatim adalah diagram batang dan diagram pie. Efektivitas dari penggunaan infografis berupa grafik pada perancangan buku profil UPN 
"Veteran" Jatim dapat diukur melalui hasil kuesioner yang telah disebarkan kepada 50 responden. Dari hasil kuesioner dapat disimpulkan bahwa sebesar $87,8 \%$ (sangat kuat) setuju jika penggunaan infografis berupa grafik pada perancangan buku profil UPN "Veteran" Jatim dapat memiliki tampilan visual yang lebih menarik. Kemudian juga dapat disimpulkan sebesar 81,8\% (sangat kuat) setuju jika penggunaan infografis berupa grafik pada perancangan buku profil UPN "Veteran" Jatim dapat menyajikan informasi menjadi lebih mudah dipahami (Gambar 9 dan Gambar $10)$.

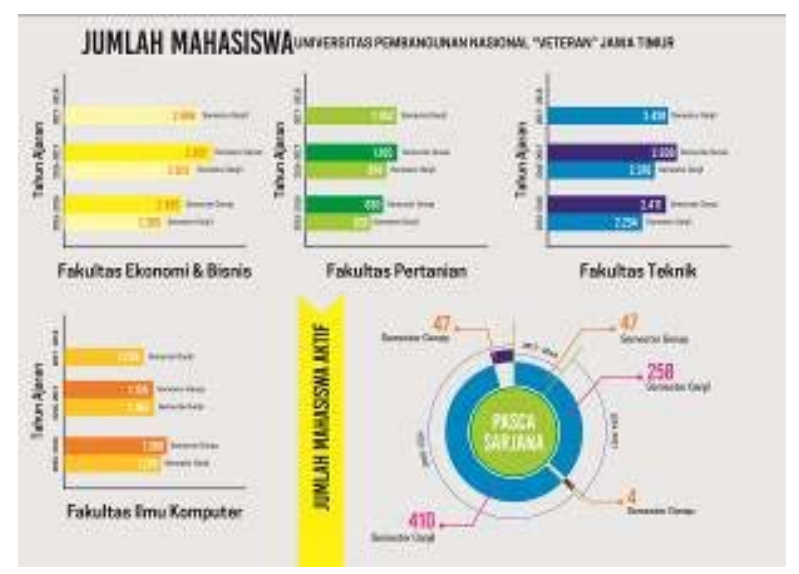

Gambar 10. Penggunaan teknik infografis berupa grafik dalam penyampaian informasi jumlah mahasiswa UPN "Veteran" Jatim.

\section{KESIMPULAN}

Kesimpulan yang dapat ditarik dari pengukuran efektivitas penggunaan infografis berupa unsur grafis, ilustrasi, pictogram, dan grafik pada perancangan buku profil UPN "Veteran" Jatim adalah sebagai berikut:

1. Sebesar $83 \%$ (sangat kuat) setuju jika penggunaan infografis berupa unsur grafis, ilustrasi, pictogram, dan grafik pada perancangan buku profil UPN "Veteran" Jatim dapat memiliki tampilan visual yang lebih menarik.

2. Sebesar $83,2 \%$ (sangat kuat) setuju jika penggunaan infografis berupa unsur grafis, ilustrasi, pictogram, dan grafik pada perancangan buku profil UPN "Veteran " Jatim dapat menyajikan informasi menjadi lebih mudah dipahami.

\section{DAFTAR PUSTAKA}

[1] Lankow, Jason. 2014. Infografis Kecerdasan Cara Bercerita Visual. Jakarta: Kompas Gramedia.

[2] Amalia E, Maulana. 2009. Consumer Insight via Enthnography. Jakarta: Erlangga.

[3] Daymon, Christine \& Holloway, Immy. 2002. Qualitative Research Methods in Public Relations \& Marketing Communications. Terjemahan: Cahya Wiratama. Bandung: Mizan Media Utama.

[4] Hamidi. 2007. Metode Penelitian dan Teori Komunikasi. Malang: Universitas Muhammadiyah Malang.

[5] Kasiram, Mohammad. 2008. Metode Penelitian KuantitatifKualitatif. Malang: UIN Malang Press.

[6] Kasilo, Djito. 2002. Komunikasi Cinta: Menembus G-Spot Konsumen Indonesia. Jakarta: PT. Gramedia.

[7] Obed, Wicandra. 2006. Peran Infografis Pada Media Masa Cetak. Infografis Universitas Kristen Petra. Fakultas Seni dan Desain. Surabaya.

[8] Rustan, Surianto. 2009. LAYOUT dasar \& penerapannya. Jakarta: Gramedia Pustaka Utama.

[9] Sarwono, Jonathan \& Lubis, Hary. 2007. Metode Riset Untuk Desain Komunikasi Visual. Yogyakarta: Andi.

[10] Sihombing, Danton. 2001. Tipografi Dalam Desain Grafis. Jakarta: Gramedia Pustaka Utama.

[11] Smiciklas, Mark. 2012. The Power of Infographic: Using Pictures to Communicate and connect with your audiences. Que Publishing.

[12] Tinarbuko, Sumbo. 2010. Semiotika Komunikasi Visual. Yogyakarta: Jalasutra. 